\section{Die funksie van verwysings na fisiese families in die Johannesevangelie}

J G van der Watt

(Universiteit van Pretoria)

\section{ABSTRACT}

\section{The function of the references to physical families in the Gospel according to John}

References to physical families in John's Gospel are rarely discussed in secondary literature - the emphasis usually falls on the spiritual aspects. In this article the references to physical families are analysed, and it is illustrated that these references, with exception of the references to Maria, are normally used to serve as contrast to the spiritual references. Since one's family and place of origin determine one's status and identity, the author of the Gospel emphasises that what should determine one's identity is not Jesus' earthly origin, but his heavenly origin. The same applies to his disciples.

\section{INLEIDING}

Die Johannesevangelie word dikwels as " $n$ "geestelike" Evangelie beskryf en met goeie rede. Dit gee daartoe aanleiding dat min aandag in kommentare of artikels geskenk word aan die aardse of fisiese aspekte wat in die Evangelie aangetref word.

In die sekondêre literatuur word Jesus se mensheid gewoonlik net vermeld om te toon dat Jesus nie 'n skynmens was nie en dat die Gnostiese raamwerk, wat in die middel van die vorige eeu so gewild was as verklaringsbeginsel vir die teologiese verskynsels in die Johannesevangelie $^{1}$, nie as enigste basis vir die verstaan van die Evangelie gebruik moet word nie.

Onversigtige opmerkings in die verband, soos die van Osiek en Balch $^{2}$ (1997:143), het ook nie gehelp nie ${ }^{3}$. Volgens hulle is daar "not

\footnotetext{
' Sien die bekende bydraes van die Bultmannskool. Ter illustrasie kan Bultmann (1978), Käsemann $(1968)$ en Dodd $(1978,1979)$ se boeke hier vermeld word. Die literatuur wat gedurende hierdie periode uit omtrent alle oorde verskyn het, beklemtoon dikwels die moontlike gnostiese verwantskap met temas uit die Evangelie. Die tendens was so algemeen in die sekondêre literatuur dat verdere individuele verwysings nie hier gemaak hoef te word nie.

${ }^{2}$ Osiek en Balch (1997:143; sien ook 162).
}

much specific information about family life in the Gospel of John"4. Daar bestaan dus nie werklike belangstelling in hierdie faset van die boodskap van die Evangelie nie.

In Family of the King is daar egter breedvoerig geilllustreer dat die beeld van ' $n$ antieke familie ' $n$ basiese raamwerk vir die ontwikkeling van die Johannesteologie vorm. Die fokus het egter aldaar geval op die metaforiese en dus geestelike fasette van die familiale beeld. In hierdie artikel word die fokus ietwat verskuif na ' $n$ verwaarloosde faset in die Johannese navorsing, naamlik fisiese families in die Evangelie. Verwysings na fisiese families word nagegaan en die funksie - indien enige spesiale funksies aangedui kan word - word ondersoek.

\section{VERWYSINGS NA FISIESE FAMILIES}

In teenstelling met Osiek en Balch se opmerking hierbo, is daar verbasend baie verwysings na fisiese families in die Evangelie. Daar is verskeie verwysings na Jesus se familie, sy pa en ma, na sy broers ${ }^{6}$, asook na sy plek van herkoms?

Daar is ook verwysings na ander families, waarvan die Lasarusfamilie waarskynlik die bekendste is (hoofstuk 11 en 12:1-8). Dan is daar ook die familie van die man wat blind gebore is - sy familie word ook direk by sy verhaal betrek (hoofstuk 9). 'n Intieme verhaal kry ons in 4:46-53 waar die vader vir sy seun by Jesus kom pleit. Algemene verwysings na, byvoorbeeld, voorvaders of vaders ${ }^{8}$, broers ${ }^{9}$ en hulle familiale verbintenisse ${ }^{10}$, asook na ander familieverhoudinge word aangetref".

\section{JESUS SE FAMILIE}

Malina en Neyrey toon aan hoe belangrik inligting oor ' $n$ persoon se geboorte en herkoms is vir die evalusie van daardie persoon ${ }^{12}$. Verskeie aspekte word in berekening gebring, soos die ouers ${ }^{13}$ en res van die

\footnotetext{
${ }^{3}$ Barton (1992:103) verwys ook na die feitlike afwesigheid van verwysings na fisiese kinders.

${ }^{4}$ Osiek en Balch (1997:143)

${ }^{5}$ Van der Watt $(2000)$

${ }^{6}$ Byvoorbeeld $1: 45 ; 2: 1,12 ; 6: 42 ; 7: 3-10 ; 19: 25-26$.

${ }^{7} 1: 45-46 ; 4: 43-44 ; 7: 41$ - sien ook die Betlehemtradisie in 7:41-42.

${ }^{8}$ Sien $4: 5,12,20 ; 6: 31,49,58 ; 7: 22,42 ; 8: 33,37,39,56 ; 13: 2,26 ; 18: 13$.

${ }^{9} 1: 40-41 ; 6: 8$.

${ }^{10} 1: 42 ; 21: 15,16,17$

$18: 15-16 ; 19: 12$.

${ }^{12}$ Malina en Neyrey (1996:23-26).

${ }^{13}$ Aristoteles (Rhet. 1.5.5, 1360b), Plato (Menex. 237) en Quintilius (Inst. Orat. 5.10 .24 ) verwys na die direkte oorerflike verband tussen vaders en seuns.
}

ISSN 1609-9982 = VERBUM ET ECCLESIA Jrg 22 (1) 2001 
gesin, die etniese affiliasie ${ }^{14}$, die tuisdorp, voorvaders en die geboorte self, byvoorbeeld of daar spesiale tekens of voorbodes was. Die aspekte wat hierbo genoem is, speel ' $n$ bepalende rol in die beoordeling van ' $n$ persoon se eervolheid al dan nie. "To know someone means to know their roots, ancestry, and genealogy"15. Onbelangrike persone sal noodwendig uit onbelangrike families, minderwaardige areas en laer klas dorpe $\mathrm{kom}^{16}$. Wat ' $\mathrm{n}$ persoon is, kan dus terug herlei word na sy oorsprong, beide fisies en geografies ${ }^{17}$. Die individu dra die kwaliteite van die groep in homself rond, byvoorbeeld Grieke en Romeine sal nie optree soos ander volke nie ${ }^{18}$.

Binne hierdie raamwerk van antieke beoordeling van ' $n$ persoon verkry die opmerkings wat in die Johannesevangelie oor Jesus en sy familie ${ }^{19}$ gemaak word, besondere reliëf.

\section{1 “Kan daar iets goeds uit Nasaret in Galilea kom?"}

Filippus bring die berig aan Natanael dat hulle die Een van wie Moses en die profete geskryf het, gekry het. Hy is die seun van Josef uit Nasaret

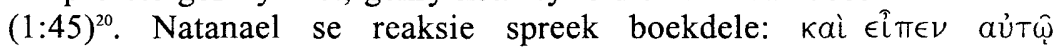

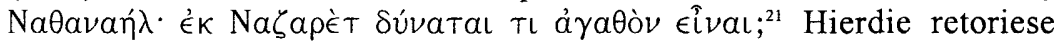
vraag impliseer dat niks goeds uit Nasaret kan kom nie, veral nie die Messias nie. ${ }^{22}$ Dit is ' $n$ ironiese refleksie op Jesus se persoon en identiteit $^{23}$. Die uitnodiging om te kom kyk, met Natanael se gevolglike gesprek met Jesus, oortuig Natanael om in 1:49 uit te roep: "Rabbi, $U$ is

${ }^{14}$ Etniese oorsprong kon ook ' $n$ persoon se karakter bepaal. Dit is gebaseer op stereotipes uit daardie tyd. Die een groep sou dapper gewees het en die ander weer wetteloos, en so voorts. Sien Malina en Neyrey (1996:26).

${ }^{15}$ Malina en Neyrey (1996:24).

${ }^{16}$ Aristoteles (Rhet. 1.5.5, 1360b) bespreek die saak.

${ }^{17}$ Soos Ferguson (1990:53-54) aandui, was die die antieke familie (in onderskeid van "n moderne familie) die "basic unit of society". Vanuit hierdie eenhede is die gemeenskap as geheel opgebou en is stereotipes oor bepaalde groepe mense ook erken.

${ }^{18}$ Vir meer volledige besprekings sien Malina en Neyrey (1996). Hulle pas die beginsels deurgaans in die boek toe.

19 Bösen (1998:128) is korrek as hy sê: "daß Jesus in Nazaret 'eine nähere Verwandschaft' hat, daß er in einen 'Clan', in eine 'Sippe' oder in eine Großfamilie eingebunden ist”. Binne daardie groep moes Jesus sy verantwoordelikhede opgeneem het.

${ }^{20}$ Neyrey (1996:119) onderstreep dat die stad of area waar ' $n$ mens woon ' $n$ tipiese kriterium was vir die bepaling van ' $n$ mens se status. Sien Carson (1991:159-160).

2I "Maar Natanael sê vir hom: 'Kan daar uit Nasaret iets goeds kom?"' $(1: 46)$.

${ }^{22}$ Nasaret word nie in die Ou Testament of die Talmud genoem nie - sien Barrett (1978:184) wat op die onbelangrikhede van die plek in die Joodse tradisie kan dui. Sien ook Bultmann (1978:73), Wilckens (1998:50).

${ }^{23}$ Carson (1991:159-160)

DIE FUNKSIE VAN VERWYSINGS die Seun van God; U is die Koning van Israel!" Dat Jesus vir hom kon sê waar hy was, het Natanael van Jesus se "goddelike konneksies" oortuig. So ' $n$ persoon het noodwendig hoër status in die gemeenskap gekry ${ }^{24}$. Natanael erken dus dat die identiteit van Jesus nie deur sy aardse herkoms bepaal word nie. Soos Schenke ${ }^{25}$ dit stel: "Das Menschsein Jesu und seine Herkunft sind kein Gegenargument gegen Jesu Hoheit". Daarmee word die gedagte deurbreek dat Jesus se identiteit deur sy herkoms uit Nasaret verklaar moet word. Die geïmpliseerde leser weet immers reeds uit die Proloog $(1: 13,14,18)$ dat Jesus se herkoms nie uit Nasaret was nie, maar van die Vader.

Hierdie verwysing na Jesus se oord van herkoms, beklemtoon dus dat Jesus die beperkinge van die stereotipes van Nasaret oorskry. Wie Hy is moet nie aan Nasaret gekoppel word nie. Twee ander belangrike verwysings sluit by hierdie motief in die Evangelie aan.

In 7:41-42 word die volgende gesê:

${ }^{41}$ Party het gesê: "Hy is die Christus."

Maar party het gesê: "Die Christus kom tog nie uit Galilea nie?

${ }^{42}$ Die Skrif sê mos die Christus kom uit die nageslag van Dawid en uit Betlehem, die dorp waar Dawid was." ${ }^{26}$

Vir ons doeleindes is die volgende twee sake van belang.

(a) Die Messias is nie uit Galilea verwag nie, of so blyk dit uit die teks ${ }^{27}$. Dit algemene stereotipe was dat met Jerusalem as religieuse sentrum, Judea die voorkeurgebied was wat sosiale en religieuse status betref. Die koninklike Messias is dus nie uit Galilea verwag nie, maar uit die gebied waar konings vandaan kom - Judea en spesifiek Betlehem, die dorp van Dawid. Die Skrif sê dit tog ook (7:42)! Jesus kwalifiseer eenvoudig nie vir hierdie koninklike status nie, want al die mense weet tog waar Jesus vandaan kom (7:27). Hier kry ons dus weereens, soos in die geval van Natanael, ' $n$ negatiewe verwysing na die fisiese herkoms van Jesus.

(b) Die tweede saak wat opgemerk moet word, raak die Betlehemtradisie. Hoewel die skrywer van die Evangelie toon dat hy bewus is van

${ }^{24}$ Sien Malina en Neyrey (1996:31) vir die wyse waarop hierdie saak in die antieke wêreld gewerk het.

${ }^{25}$ Schenke (1998:49)

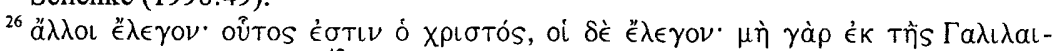

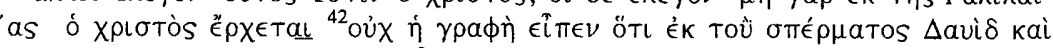

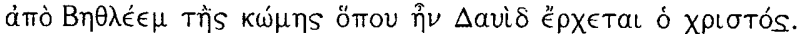

${ }^{27}$ Lindars (1987:302-303) meen dat volgens gedeeltes in die Ou Testament, soos Jesaja 9:1vv, daar ' $n$ tradisie is dat die messias uit Galilea moet kom en dit is wat hier in Johannes aangetref word.

ISSN 1609-9982 = VERBUM ET ECCLESIA Jrg 22 (1) 2001 
die Betlehemtradisie ${ }^{28}$ en al die kans het om die tradisie in 7:41-42 te benut ten einde die status van Jesus as Messias deur die argument te ondersteun, doen hy dit nie. Hy handhaaf die standpunt dat Jesus uit Galilea en nie uit die elite gebied nie, kom. In die lig van hoe antieke persoonlikhede beoordeel is - soos dit hierbo uiteengesit is - reflekteer dit negatief op Jesus. In die lig van Matteus en Lukas is dit beslis ' $n$ wegbeweeg van die vroeg-Christelike tradisie. Aangesien die skrywer bewus was van die Betlehemtradisie, moet gekonkludeer word dat hy bewustelik nie die tradisie benut het nie. Die vraag wat beantwoord moet word, is waarom? $?^{29}$

Die rede vir hierdie herinterpretasie moet in die Christologie gesoek word en kan retories moontlik as ironiese misverstand gesien word, soos Carson voorstel ${ }^{30}$. Jesus se geboorte word nie beskryf nie, maar net genoem: Hy het vlees geword en onder ons kom woon $(1: 14)^{31}$. Die belangrike was egter dat ons sy heerlikheid moet sien. Die heerlikheid word

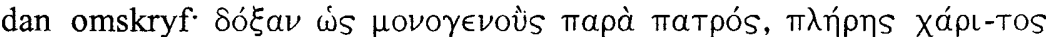

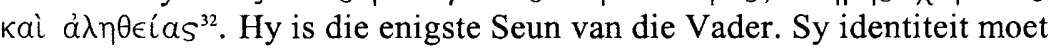
dus nie in terme van die fisiese herkoms gemeet word nie, maar in terme van sy figuurlike hemelse herkoms ${ }^{33}$. Op die wyse onderbeklem-toon die skrywer van die Evangelie Jesus se fisiese herkoms ten gunste van sy hemelse herkoms. Uit die hemel is Jesus gestuur en dit is waar sy identiteit gesoek moet word $^{34}$. Hy kom eintlik van die bors van die hemelse Vader af (1:18). Sy fisiese herkoms uit Galilea word in die lig van hierdie hemelse herkoms eintlik as irrelevant gesien. "It follows that all disputes about the birth place of the Messiah, the heavenly Man, are far wide of the point" ${ }^{\prime 35}$.

\footnotetext{
${ }^{28}$ Sien Matteus 1-2 en Lukas 1-2 waar die tradisie aangetref word.

${ }^{29}$ Die vraag is dus waarom Johannes nie die Bethlehemtradsie opneem of ontwikkel nie. Barrett (1992:330) skryf dit aan tipiese Johannese ironie toe. Wilckens (1998:136-137) meen 'n duidelike antwoord op die probleem is nie moontlik nie, maar in alle geval moet daar nie ' $n$ bewustelike polemiek van die kant van Johannes teen die Betlehemtradisie veronderstel word nie. Schnelle (1998:55) meen dat Johannes die Betlehemtradisie teenstaan, terwyl Schenke (1998:164) die "afwysing" van die Bethlemhemtradisie as ironie sien - hy meen dat die Christelike leser tog weet dat Jesus in Bethlehem gebore is. Sien ook Schnackenburg (1980:157-159).

${ }^{30}$ Carson (1991:329-330)

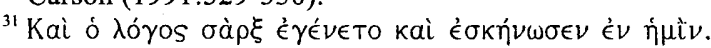

32 “...die heerlikheid wat Hy as die enigste Seun van die Vader het, vol genade en waarheid".

${ }^{33}$ So ook Barrett (1978:331); Carson (1991:330).

${ }^{34}$ Die motief van Jesus wat uit die hemel kom is algemeen in die Evangelie - sien

$1: 18 ; 3: 16,31-36$ ensovoorts. Schnackenburg (1980:158-159).

${ }^{35}$ Barrett (1978:331).
}

Kortom, Jesus se aardse herkoms dra nie tot sy eer by nie, want Hy kom van die Vader in die hemel. ' $n$ Hoër en beter herkoms as dit kan niemand hê nie. Die verwysings na die aardse herkoms van Jesus dien as kontras vir die grootheid van die Here wat uit sy hemelse herkoms blyk.

In 4:43-44 word vertel van Jesus wat na sy eerste besoek aan Jerusalem na Galilea toe teruggaan. Die tradisionele uitdrukking ${ }^{36}-$ dat ' $n$ profeet nie in sy eie land geëer word nie ${ }^{37}$ - word aangehaal. In die sinoptiese evangelies word die uitdrukking gekoppel aan die Jode wat Jesus uit die sinagoge gejaag het ${ }^{38}$. In Johannes word hierdie woorde egter herinterpreteer. Jesus het dit wel gesê, maar as Hy in Galilea kom, word Hy met ope arms ontvang (4:45), veral na sy wonders in Jerusalem. Die rede vir hulle gulle ontvangs lê waarskynlik in die eer wat Jesus in Jerusalem verwerf het - sy eer is hulle eer volgens antieke konvensie. Iemand wat wonders doen, bewys so sy positiewe verhouding met God en moet dus spesiale status hê. So gesien, het Jesus nie eer omdat Hy uit Galilea kom nie, maar Galilea deel aan die eer wat Hy in Jerusalem verwerf het. Daarom ontvang Galilea Hom met ope arms.

Dit is opmerklik dat die gedeeltes waar dit om Jesus se lokale oorsprong gaan, dit in ' $n$ negatiewe lig staan. Niks goeds kom uit Nasaret nie, en 'n profeet kom nie uit Galilea nie. Die moontlikheid van 'n positiewe benutting van lokaliteit, naamlik die Betlehemtradisie, word nie gebruik nie. Geoordeel aan Jesus se fisiese geografiese herkoms, wat tot sy posisie en eer moet bydra, is daar niks om positief oor te voel nie. Inteendeel, dit maak ook nie saak nie, want Jesus se herkoms is van bo.

\subsection{Ons ken sy ma en pa! Jesus se ouers}

\subsubsection{Jesus se pa, Josef}

In reaksie op Jesus se woorde dat Hy die brood is wat uit die hemel kom,

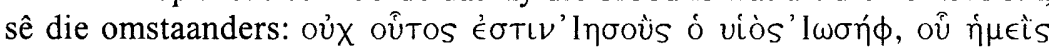

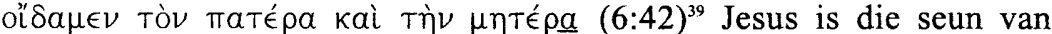
Jose $^{40}$ en die omstanders ken die familie ${ }^{41}$. Retories funksioneer die

\footnotetext{
${ }^{36}$ Sien Barrett (1978:246) vir ' $n$ bespreking van hierdie spreuk. Schnelle (1998:95) beweer dat hierdie spreuk uit die profane literatuur kom.

${ }^{37}$ Lindars (1987:200-201) argumenteer dat hierdie spreuk van Jesus nie op die hele Galilea van toepassing is nie, maar alleen op Nasaret. Dit verklaar dan ook waarom die Galileërs Hom met ope arms ontvang het. Schnackenburg (1968:462) argumenteer dat Tarpís wel na Galilea verwys.

${ }^{38}$ Sien Matteus 13:57; Markus 6:4; Lukas 4:24.

39 "Is dit nie Jesus die seun van Josef nie? Ons ken mos sy pa en ma". Dit is in teenstelling met 9:29-30 waar die Joodse leiers nie weet waar Jesus vandaan kom nie. Die sinspeling hier is dat hulle nie sy goddelike herkoms ken nie.

${ }^{40}$ Schnelle (1998:55) meen dat dit volgens hierdie beskrywing wil voorkom asof Josef Jesus se fisiese pa was. Lindars (1987:117) onderstreep dat hierdie verwysings
}

ISSN 1609-9982 = VERBUM ET ECCLESIA Jrg 22 (1) 2001 
opmerking in hoofstuk 6 negatief-ironies in die konteks. Jesus beweer dat Hy uit die hemel kom, maar omdat die omstanders sy ouers glo ken, meen hulle dat Jesus dus nie ook uit die hemel kan kom nie ${ }^{42}$. Vir die Joodse leiers moet Jesus noodwendig soos Josef en Maria lyk en optree. Die ironiese misverstand ${ }^{43}$ lê daarin dat die strekking van die gesprek in hoofstuk 6 juis is dat Jesus van die Vader uit die hemel kom - dáár lê sy oorsprong ${ }^{44}$. Weereens word Jesus se fisiese ouers nie ontken nie, maar dien dit juis as kontras vir die outeur van die Evangelie om Jesus se hemelse herkoms te onderstreep. Jesus het wel vlees geword (1:14), maar sy ware herkoms is van bo.

'n Verdere verwysing na Josef as Jesus se pa kry ons toe Filippus

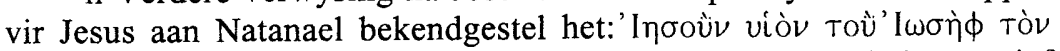

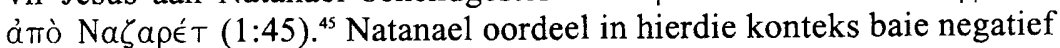
oor hierdie herkoms. Nasaret kan - na verwagting - niks goeds oplewer nie. Immers, wat ' $n$ mens is en waartoe jy instaat is, kan vanuit jou herkoms vasgestel word. Jesus se profetiese vermoëns verander egter Natanael se opinie (1:46-51). Jesus se optrede bewys dat Hy bo die stereotipe van familie en area uitstyg.

Ons kan dus konkludeer dat as dit by die aardse vader van Jesus kom, hy nie deur die Evangelie ontken word nie, maar dat die feit bioot as kontras gebruik word om Jesus se herkoms van die hemelse Vader te beklemtoon. Jesus is nie soos sy aardse vader nie. Daarom is die aardse vader ook nie sy werklike vader nie - Jesus aard na sy hemelse Vader aan wie se boesem hy was voor die skepping van die aarde (lees 1:1 en $1: 18$ saam).

\subsubsection{Jesus se ma, Maria}

Ons ontmoet Jesus se ma, Maria, die eerste maal by die bruilof in Kana $(2: 1-12)$, waar sy Jesus konfronteer met die probleem dat daar nie meer wyn oor is nie (2:3). Jesus se reaksie klink negatief afwysend (2:4):

na Josef daarop dui dat Josef eintlik nie belangrik was nie - daarom kan Jesus ook nie eintlik belangrik wees nie.

${ }^{41} \mathrm{Kennis}$ van iemand in die antieke tyd was nie maar toevallige kennis nie - dit het beteken dat ' $\mathrm{n}$ mens die persoon se aard ken, want jy weet wie se kind die persoon is en van waar die persoon kom. Díe kennis help jou om te voorspel wat jy van die persoon kan verwag, aangesien beide genetiese en geografiese herkoms bepalend was vir die aard en optrede van ' $n$ persoon. Sien Malina en Neyrey (1996:23vv).

${ }^{42}$ Barrett (1978:295); Wilckens (1998:103).

${ }^{43}$ Sien Schnackenburg (1971:276-277).

${ }^{44}$ Lees maar verse soos 6:32-33 of 6:38-40. Sien ook Schnelle (1998:128), Carson (1991:292).

${ }_{45}$ "Dit is Jesus van Nasaret, die seun van Josef". Sien Barrett (1978:184) hieroor.

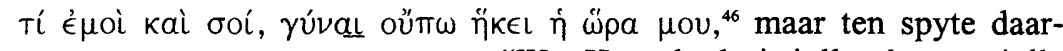
van reageer sy ma met vertroue: "Wat Hy ook al vir julle sê, moet julle doen" (2:5)

Twee aspekte in hierdie verhaal is vir ons doeleindes interessant.

(a) Hoewel Jesus in 2:4 voorgee dat die wynprobleem Hom nie eintlik aangaan nie, verander Hy tog die water in wyn. Wat Hy dus doen, gaan skynbaar teen sy eie woordelikse reaksie teenoor sy ma in. So kry $\mathrm{Hy}$ die geleentheid om te toon dat $\mathrm{Hy}$ die figuurlike hemelse Bruidegom is ${ }^{47}$. Hoewel die fyner eksegetiese nuanses van hierdie gedeelte nie hier bespreek kan word nie, moet enkele motiewe tog uitgelig word.

Jesus wys sy moeder se versoek oënskynlik af omdat sy tyd nie daar is nie, maar doen dan later wat gevra is. Dieselfde gebeur in hoofstuk 7 waar sy broers vir Hom sê om Jerusalem toe te gaan (7:2-5). Hy sê dat sy tyd nog nie gekom het nie - sy broers moet maar gaan (7:6-8). Kort daarna gaan $\mathrm{Hy}$ tog. Waarom sê Jesus eers nee en doen dan tog wat gevra word? Die koppeling van sy optrede aan die regte tyd, sinspeel op die "groter program" van sy hemelse Vader, soos uitgedruk is sy verwysing na sy 'uur' oftewel die goddelike tydskedule ${ }^{48}$. Sy ma en broers skryf nie vir Hom voor nie en hy luister ook nie na hulle nie, maar Hy volg die program van sy hemelse $\operatorname{Vader}^{49}$. Hoewel 'n mens in die antieke tyd die versoeke van jou familie ernstig moes neem en altyd bereid moes wees om jou vriende te help ${ }^{50}$, wys Jesus daardie versoeke af om so te wys dat sy gehoorsaamheid deur ' $n$ ander familie bepaal word, naamlik deur sy hemelse Vader.

46 "Waarom sê u dit vir My? My tyd het nog nie gekom nie." Let op die wyse waarop die NAV die rúval hier wegvertaal het.

${ }^{47}$ Dit was die bruidegom se taak om die wyn te verskaf - deurdat Jesus dit gedoen het, het Hy eintlik die werk van die bruidegom oorgeneem en so implisiet getoon dat Hy die figuurlike hemelse Bruidegom is. Later in 3:30-31 word Jesus ook as figuurlike hemelse Bruidegom beskryf en in hoofstuk 4 mag daar sulke sinspelings wees.

${ }^{48}$ Sien Schnackenburg (1968:328-330) oor die verwysing na die "uur" in hierdie gedeelte.

${ }^{49}$ Met die verandering van water in wyn maak Jesus baie meer en beter wyn as wat enigiemand - ook sy ma - verwag het. Dit word " $n$ "teken" daarvan dat Hy die figuurlike hemelse Bruidegom is. In hoofstuk 7 gaan Jesus Jerusalem toe en vervang die elemente van die huttefees, soos ons in 7:39-40 sien. In elke geval doen Jesus iets heeltemal anders as wat sy aardse familie verwag (sien hulle verwagting in 7:34). Sien ook Schnelle (1998:60), Carson (1991:171).

${ }^{50}$ Omdat Jesus na die bruilof uitgenooi is, kan ons aanneem dat Hy die families wat by die troue betrokke was, geken het. In die antieke tyd was dit ononderhandelbaar dat vriende vriende moes help. Jesus beweeg hier dus teen die sosiale verwagtings in.

ISSN 1609-9982 = VERBUM ET ECCLESIA Jrg 22 (1) 2001 165 
(b) Die moderne verklaarders het meer probleme met Jesus se reaksie in 2:4 teenoor Maria as wat Maria skynbaar self gehad het ${ }^{51}$. Dit blyk onder andere uit die weglating van yúvaı in die NAV se weer-gawe van $2: 4^{52}$. Tog blyk dit uit die konteks dat Jesus se reaksie haar skynbaar nie steur nie. Sy ervaar sy woorde nie as verwerping of afsy-digheid nie $\mathrm{e}^{53}$, want in 2:5 sê sy vir die kelners: "Wat Hy ook al vir julle sê, moet julle doen". Daaruit blyk haar vertroue dat Hy iets gaan doen. Binne die konteks blyk dit dat Maria iets verstaan het van Jesus se groter hemelse program.

$\mathrm{Na}$ die bruilof is Hy, met sy ma, broers en dissipels na Kapernaum toe $(2: 12)$. In $2: 11$ word daar egter vermeld dat sy dissipels tot geloof gekom het. Niks word egter van sy familie gesê nie. Dit berei die leser voor vir die verhaal in 7:1vv waar daar gesê word dat sy broers nie in Hom geglo het nie $(7: 5)$. Hulle het nog nie die verband getrek tussen Jesus se aksies en sy hemelse herkoms nie.

Die patroon wat tot dusver geblyk het, naamlik die kontrastering van die aardse familiale aspekte met die hemelse, word in die gedeelte ook gevind. Die aardse realiteit word nie ontken nie, maar in die lig van die figuurlike hemelse familiale verbande gerelativeer. Maria reageer egter nie negatief daaroor nie.

Behalwe vir 6:42, waar die klem - soos reeds aangedui is - meer op Josef val, tref ons Maria eers weer by die kruis saam met haar suster $\operatorname{aan}^{54}$. In 19:25-27 lees ons die volgende:

"By die kruis van Jesus het ook nog sy moeder en sy moeder se suster en Maria, die vrou van Klopas, en Maria Magdalena gestaan. Toe Jesus sy moeder sien en die dissipel vir wie Hy baie lief was, wat by haar staan, sê Hy vir haar: "Daar is u seun". Daarna sê Hy vir die dissipel: 'Daar is jou moeder'. Van daardie oomblik af het die dissipel haar in sy huis geneem"ss.

${ }^{51}$ Sien die beskrywing by Carson (1991:170-171), Kysar (1986:44-45). Brown (1971:99). Lindars (1987:129) beweer dat dit ' $n$ normale aanspreekvorm is.

52 "Waarom sê u dit vir My? My tyd het nog nie gekom nie." Barrett (1978:191) gee egter ' $n$ goeie bespreking van die manier waarop hiedie woorde verstaan kan word en meen gevolglik dat dit nie as skerp of aanstootlik gelees moet word nie. Sien Schnackenburg (1971:99-100)

${ }^{53}$ So ook Barrett (1978:191). Wilckens (1998:57) meen dat Maria verstaan het wat Jesus bedoel.

${ }^{54}$ Sien Barrett (1978:551) en Carson (1991:615-616) vir die verklaring van die verhoudinge in hierdie gedeelte.

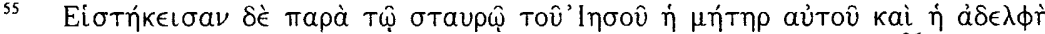

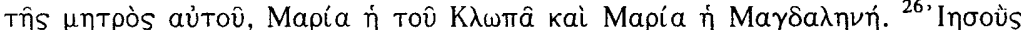

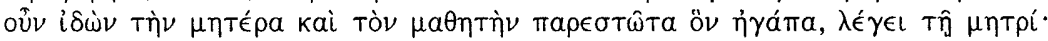

Sy moeder is by die kruis, met haar suster, wat haar waarskynlik bygestaan het soos wat destyds van familie verwag is ${ }^{56}$. Jesus, as oudste seun, was verantwoordelik vir die versorging van sy moeder (in die geval waar die vader oorlede was). Die normale sou wees dat een van sy broers die verantwoordelikheid sou oorneem ${ }^{57}$. Jesus se "testament" lui egter anders $^{58}$. Hy sien sy geliefde dissipels by sy moeder staan. Die geliefde dissipel is nie deel van sy fisiese familie nie, maar is ' $n$ volgeling en vriend van Jesus ${ }^{59}$. Jesus vra sy vriend om na sy moeder om te sien en dit het hy dan ook gedoen. Hier is ' $n$ duidelike wisseling van sosiale relasies. Die geliefde dissipe ${ }^{60}$ was primêr deel van die figuurlike hemelse familie wat Jesus op aarde kom vestig het en so word Maria ook in die familie opgeneem ${ }^{61}$.

Weer eens word die fisiese families nie geïgnoreer nie (Jesus se tante staan sy ma by), maar die klem word verskuif na die figuurlike hemelse familie. Maria word weer positief beoordeel, soos in die geval van die bruilof te Kana.

\subsubsection{Jesus se broers}

Jesus se broers word in twee gevalle in die Evangelie vermeld, terwyl sy susters $^{62}$ glad nie vermeld word nie ${ }^{63}$. In 2:12 word daar gesê dat Jesus saam met sy ma, broers en dissipels na Kapernaum gegaan het. Sy broers het ook die wonder te Kana gesien, maar het nie in Jesus geglo nie (7:5).

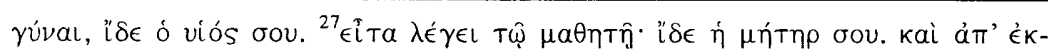

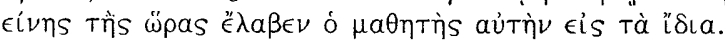

${ }^{56}$ Jou familie was jou primêre ondersteuningsisteem. Verwerping van hulle kant af was uiters negatief beoordeel. Sien Schnackenburg (1982:277).

${ }^{57}$ Barrett (1978:552) bespreek hierdie konvensies

${ }^{58}$ Sien Schnelle (1998:288) wat na die familiale implikasies hiervan verwys. Kysar (1986:288-289), Schnackenburg (1972:922-927).

${ }^{59}$ Sy broers was oënskynlik nie daar nie.

${ }^{60}$ Die feit dat sy naam nie genoem word nie, maar dat hy in terme van liede - wat die kenmerkende eienskap van die figuurlike hemelse familie is (bv. 13:34-35) beskryf word, onderstreep dat die hier om meer as bloot ' $n$ aardse reëling gaan.

${ }^{61}$ Sien Van der Watt (2000:333-335) en Carson (1991:616-620) vir ' $n$ meer volledige bespreking hiervan. Die waarnemings is in lyn met Barton (1992:229) wat Collins aanhaal met die woorde dat Maria "symbolizes the one who faithfully awaits the messianic times". Sien ook Barrett (1978:552). Wilckens (1998:295-296) gee "n volledige uiteensetting van die opname van Maria in die familie van God.

${ }^{62}$ Sien Markus 3:31-35 par; 6:3 par.

${ }^{63}$ Sien Barrett (1978:310-311) oor Jesus se broers. Kysar (1986:117) sien die ongeloof van Jesus se broers as die teken van hulle gevangenskap in die aardse, menslike duisternis. Dit staan in kontras met Jesus se hemelse herkoms.

ISSN 1609-9982 = VERBUM ET ECCLESIA Jrg 22 (1) 2001 
Hulle opmerking dat Hy na Jerusalem toe moet gaan, bloot omdat Hy eer soek, mag as sarkasme of ironie gesien word ${ }^{64}$.

Die oordeel wat die Evangelie dus oor Jesus se broers fel is negatief. Barton ${ }^{65}$ maak ' $n$ interessante opmerking, naamlik dat die beklemtoning op die ongeloof van die broers van Jesus juis die funksie het om Jesus van sy fisiese familie te ontkoppel. Hy het inderdaad nie hulle ondersteuning nodig nie. Die feit dat hulle nie glo nie, maak hulle ook nie deel van die hemelse familie nie ${ }^{66}$. Weer eens word die aardse familiale bande nie ontken nie, maar relativeer in die lig van die groter taak wat Jesus van sy hemelse Vader ontvang het ${ }^{67}$.

Kortom, Jesus se aardse familie word in die Evangelie vermeld, maar speel binne die narratief nie ' $n$ prominente rol nie. Die vernaamste funksie van die vermelding van die aardse familie van Jesus is om profiel te verleen aan die figuurlike hemelse familie. Die twee families, met die lojaliteit wat aan elkeen behoort toe te kom, word telkens teenoor mekaar gestel. Sonder uitsondering toon Jesus dat sy lojaliteit aan sy hemelse Vader behoort.

Die patroon van die lojaliteit van die figuurlike hemelse familie wat in die maak van keuses die belange van die aardse familie by verre oorskrei, moet as patroon vir die gelowiges dien. In hulle keuses moet hulle ook die belang van die figuurlike hemelse familie eerste stel, al behoort hulle nog aan ' $n$ aardse familie.

\section{ANDER FAMILIES}

Daar word egter nie net na Jesus se familie in die Evangelie verwys nie. Daar word op nog drie ander fisiese familiegroepe in die Evangelie gefokus, afgesien van ander los verwysings na familiebande.

\subsection{Die familie van die regeringsamptenaar in Kapernaum}

'n Roerende prentjie word in 4:46-53 geskets van 'n pa wat Jesus vra om sy kind, wat besig was om te sterf, gesond te kom maak. Wat opvallend is, is hoe die verhaal die hele familie $\left(\right.$ oi $\kappa^{\prime} \alpha^{68}$ ) insluit

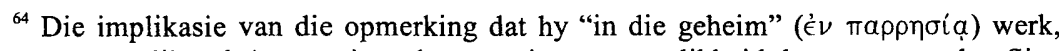
mag moontlik ook ' $n$ negatiewe konnotasie van oneerlikheid daarmee saamdra. Sien ook 18:20-21 en Barrett (1978:311)

${ }^{65}$ Barton (1992:229). Sien ook Porch (1988:76-77).

${ }^{66}$ Schnelle (1998:142).

${ }^{67}$ Sien 7:6-8 waar Jesus na sy "tydskedule" verwys, wat van sy hemelse Vader kom.

${ }^{68}$ oikía word vyf maal in die Evangelie gebruik. Die term funksioneer nie noodwendig in ' $n$ tegniese sin in die Evangelie nie, maar word op ' $n$ verskeidenheid maniere gebruik. In 4:53 en 8:35 word daar na tipiese antieke huishoudings verwys. In 11:31 en 12:13 blyk die verwysing na fisies huise te wees en in 14:2 vind ons " metaforiese verwysing na ' $n$ huis.
}

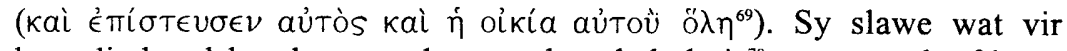
hom die boodskap kom oordra, asook sy hele huis ${ }^{70}$ wat tot geloof kom, weerspieël tipiese antieke familiale groepgeoriënteerde karakteristieke. As familie word hierdie familie dus in die figuurlike hemelse familie opgeneem op grond van hulle geloof. Dit impliseer dat hulle nou aan twee families behoort - ' $n$ aardse en ' $n$ hemelse familie.

\subsection{Die familie van die blinde man wat genees is}

Die vraag van die dissipels in 9:2 $2^{71}$ berus op tipiese antieke familiekonvensie waarvolgens die ouers se gedrag, asook die gevolge van daardie gedrag, op die kinders oorgaan, of dit nou positief of negatief is. Jesus opponeer hierdie konvensie in hierdie geval (9:3). Die familiale verbande kom egter sterk in fokus in 9:18-23, waar ' $n$ ironiese verhaal ontvou. Die ouers identifiseer die man as hulle kind, maar wil uit vrees vir die Jode en uitbanning uit die sinagoge nie verder by hulle seun betrokke raak nie. Uitbanning uit die sinagoge het sosiale afsnyding en isolasie beteken ${ }^{72}$. So ' $n$ persoon is van sy breëre sosiale ondersteuningstrukture afgesny ${ }^{73}$. Dié risiko wou die ouers nie loop nie. Hulle seun moes maar vir homself praat, wat beteken dat hulle hom aan sy eie lot oorlaat. Die normale antieke familiale ondersteuning word hom dus van hulle kant ontsê $\hat{e}^{74}$. Die keuse is gemaak: die ouers kies liewer vir sosiale anvaarding binne die breër Joodse sisteem as vir hulle intieme familiale verantwoordelikheid teenoor hulle seun. Dit staan in kontras teenoor wat die blinde man doen.

Die geneesde man verdedig Jesus tot op die punt van sy uitbanning $^{75}$. Daarmee gee hy nie alleen sy breër sosiale posisie in die samelewing prys nie, maar posisioneer hom ook teenoor sy aardse familie (sy ma en pa). Die verhaal eindig waar hierdie man in die geestelike familie van God opgeneem word (9:35-38). Hy kom tot geloof in Jesus. Sy optrede word dus nie as ' $n$ verlies in die Evangelie geteken nie, maar as wins. Om jou aardse sosiale bande te verloor ter wille van die figuurlike hemelse familiebande is ' $n$ goeie ruil. Wat jy verloor is baie minder as wat jy kry. Weereens word die aardse familiebande nie in die Evangelie

\footnotetext{
69 "En hy en sy hele huisgesin het tot geloof in Jesus gekom."

${ }^{70}$ Die groepsverbondenheid van antieke gesinne blyk uit hierdie opmerking. Sien ook Barrett (1978:248).

71 "Rabbi, deur wie se sonde is dit dat hierdie man blind gebore is: sy eie of sy ouers s'n?" Sien Kysar (1986:148-149) hieroor.

${ }^{72}$ Sien Barton (1992:229).

${ }^{73}$ Sien Barrett (1978:361-362) vir ' $n$ beskrywing van hoe hierdie sosiale aksie in die Jodendom kon gewerk het.

${ }^{74}$ Vir die familieverantwoordelikhede sien Malina en andere (1995:4-5, 18-21).

${ }^{75}$ Hierdie is die enigste verhaal in die Evangelie waar Jesus nie by is om Homself te verdedig nie. Dit beklemtoon die besondere gedrag van die geneesde man.
}

ISSN 1609-9982 = VERBUM ET ECCLESIA Jrg 22 (1) 2001 
ontken nie, maar as van minder belang teenoor die figuurlike hemelse familiebande gestel.

\subsection{Die familie van Lasarus}

Die familie van Lasarus word uitgebeeld as ' $n$ hegte groep wat mekaar se belange op die hart dra (11:1-12:11). Jesus se verhouding met hierdie familie word ook in duidelike terme uitgedruk: "Jesus het vir Marta en haar suster en Lasarus liefgehad ${ }^{76 "}$ (11:5). Die verhaal verloop volgens normale familiekonvensies" tot op " $n$ punt $^{78}$. Soos vriende doen, roep die susters van Lasarus Jesus se hulp in as hulle in die nood is ${ }^{79}$. 11:6 kom egter as verrassing, gemeet aan die vriendskapskonvensies van daardie tyd - Jesus wag twee dae voor Hy gaan om sy vriend te help. Daarom sou dit waarskynlik nie verkeerd wees om ' $n$ effens verwytende toon in Marta en Maria se woorde (in 11:21 en 11:32 respektiewelik) te hoor nie: "Marta sê toe vir Jesus: 'Here, as U hier was, sou my broer nie gesterwe het nie"' (11:21). Die rede vir Jesus se atipiese optrede word duidelik gegee - nie aardse vriendskap nie, maar die hemelse saak is vir Hom primêr: "Hierdie siekte sal nie op die dood uitloop nie maar op die openbaring van die wonderbaarlike mag van God sodat die Seun van God daardeur verheerlik kan word" (10:4).

Weer eens word die aardse realiteit nie ontken nie - Jesus was vriende met die familie en het vir Lasarus liefgehad. Juis hierdie intieme aardse verhouding word egter gebruik as agtergrond om Jesus se groter lojaliteit teenoor sy hemelse roeping te illustreer. Hy maak van hierdie situasie gebruik om sy hemelse boodskap duideliker reliëf te gee $^{80}$. In hulle smart ontdek die susters wat lewe beteken - nie net aardse lewe nie, maar ewige lewe (11:24-26).

Daar moet net weer beklemtoon word dat die aardse faset nie ontken word nie - daar word selfs vertel dat Jesus aangedaan was ${ }^{81}$

\footnotetext{
${ }^{76}$ ท่yátra word hier gebruik. Barrett (1978:388-390) bespreek hierdie filiale verhoudinge.

${ }^{77}$ Die plek waar hulle bly, asook hulle name en onderlinge familieverhoudinge word beskryf (11:1-2). Tipiese vriendskapskonvensies word in 11:19 aangetref waar mense bymekaar kom om saam met die familie te rou en hulle te troos.

${ }^{78}$ Die susters word met name voorgestel, iets wat in die Evangelie uitsonderlik is. Heelwat van die karakters in die Evangelie word nie by die naam genoem nie. Neem byvoorbeeld die Samaritaanse vrou of die Romeinse amptenaar (hoofstuk 4), die siekes wat Jesus genees (hoofstukke 5 en 9) en so meer. Die karakters wat by die naam genoem word, duik gewoonlik later weer in die Evangelie op soos Nikodemus of Malgus. In die geval van die familie van Lasarus is dit interessant dat hulle verhaal volg op hoofstuk 10 waar Jesus sê dat Hy sy skape by die naam ken (10:3).

${ }^{79}$ Malina en andere (1995:35-37).

${ }^{80}$ Sien Kysar (1986:173-174).

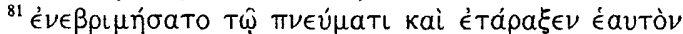

DIE FUNKSIE VAN VERWYSINGS
(11:33; sien ook vers 38 ) wat aan enige verhaal ' $n$ heel menslike noot gee. Tog maak Jesus van hierdie geleentheid gebruik om mense die wonderlike mag van God te laat sien (11:40). In 11:41-42 bid Jesus dan ook tot sy Vader en beklemtoon die goeie verhouding tussen Hom en die Vader. Dit plaas die hele Lasarusgebeure in die konteks van die figuurlike hemelse familie, waaraan Marta en Maria en al die omstanders ook deel kan word.

\section{VERWYSINGS NA FISIESE FAMILIE}

Die bewustheid van die familie as basiese sosiale struktuur word oral in die Evangelie aangetref, soos gesien kan word uit die gebruik van terme soos voorvaders, vaders, broers of susters ${ }^{83}$.

\subsection{Voorvaders}

Verwysings na voorvaders en vaders kom verskeie kere in die Evangelie voor wat natuurlik binne die sosiale ekologie van destyds boekdele spreek oor die sosiale groepsgebondenheid en inbedding van die mense: "writers and speakers begin by telling of a person's family of origin, so as to inform others of their honor rating. Social pedigree is basied on embeddedness in a social group" ${ }^{84}$. Die familie was die basiese sosiale struktuur van destyds en daarom is veral manlike lede van die gemeenskap geïdentifiseer na aanleiding van hulle vaders en voorvaders. Dit bed die persoon in binne ' $n$ groep en tradisie ${ }^{85}$. Om weer na Malina en Neyrey te verwys: "Identity ... resides not just in one's father but in one's father's father, their clan, and ultimately in the etiological ancestor of the extended family" ${ }^{\prime \prime 6}$.

Die verwysings na die voorvaders in die Evangelie gaan terug tot diep in die Ou-Testemantiese geskiedenis en volg ' $n$ interessante

\footnotetext{
${ }^{82}$ Vanweë die beperking van ruimte, gaan daar by die beskrywing van direkte familie (gesin) gebly word. Daar is ander fasette van fisiese families wat ook aandag sou kon ontvang, soos die gebruik van Tà $\iota_{\delta} \delta \iota \alpha$ in 19:27 of verder in $1: 11,7: 5$; 16:32. Die begrip kom in totaal 8 maal in die Evangelie voor, naamlik in 1:11 (tweemaal), $4: 44 ; 10: 3,4,12 ; 16: 32 ; 19: 27$. oikos word in 'n verskeidenheid van maniere in die Evangelie gebruik, byvoorbeeld as antieke huishoudings $(4: 53 ; 8: 35)$, fisiese huise $(11: 31 ; 12: 3)$ en ' $n$ figuurlike huis (14:2). Sien Barton (1992:229). Ander sosiale aktiwiteite kom ook ter sprake in byvoorbeeld die verwysing na die huwelik $(2: 1-12 ; 3: 29-30 ; 4 ; 16-18)$ en die skeiding tussen die Jode en die Samaritane (4:9).

${ }^{83}$ Daar is ook ander lede van die uitgebreide familie wat genoem word en wat vanweë ruimtebeperking nie hier bespreek word nie. Die familie van Malgus (18:26) en die blinde man se bure $(9: 8)$ word vermeld. Dan is daar ook verwysings na slawerny $(4: 51 ; 18: 10,26)$ en vriendskap $(18: 15-16 ; 19: 12)$.

${ }^{84}$ Malina en Neyrey (1996:93).

${ }^{85}$ Malina en Neyrey (1996:158-159).

${ }^{86}$ Malina en Neyrey (1996:159).
} 
kommunikatiewe patroon. Daar is veral drie gedeeltes waar die rol van die voorvaders sterk op die voorgrond tree in die argumentasie, naamlik in hoofstuk 4 met die gesprek met die Samaritaanse vrou, in hoofstuk 6 as die manna in die woestyn ter sprake kom en in hoofstuk 8 waar Jesus die optrede van die Jode in die lig van hulle herkoms plaas.

In hoofstuk 4:12 verwys die Samaritaanse vrou na haar voorouers, naamlik Jakob ${ }^{87}$ wat die put vir hulle gegee het en so gesorg het vir sy nageslag en in 4:20 verwys sy na haar voorouers wat op die berg Gerasim aanbid het. In beide die gevalle koppel die vrou haar identiteit aan die verwysings na haar voorouers. Jesus vervang egter beide die put (met die lewende water) en die plek van aanbidding ${ }^{88}$ (God word in Gees en waarheid aanbid) en bied so aan die vrou ' $n$ nuwe identiteit wat direk by God ontspring. So dien die verwysings na die voorouers hier as kontras vir die nuwe familie wat Jesus kom vestig. Soos Jesus se lewende water beter is as die put se water en die aanbidding van God in Gees en waarheid die gestryery oor op watter berg aanbid moet word (sien 4:20-22) eintlik in godsdienstige irrelevansie laat verval, so oortref die nuwe geloofsverbondenheid met Jesus die aardse verbondenhede by verre.

Dieselfde patroon word in Jesus se gesprek met die Jode na die vermeerdering van die brood aangetref (hoofstuk 6). In 6:31 verwys die Jode na hulle voorouers wat manna uit die hemel ontvang het - dit is opgeteken in die Skrif, wat die goeie daad van God aan hulle voorouers bo alle twyfel stel. Dit dien as duidelike bewys dat God aan hulle voorouers se kant gestaan het, want hoe anders kan die guns verklaar word? Jesus se regstelling in 6:32 is interressant - nie Moses nie, maar God het die manna gege ${ }^{89}$. Daarmee "ontmitologiseer" hy die gedagte dat die Jode nou spesiale kwaliteite kan eis omdat hulle die nageslag van Moses en die mense in die woestyn was. Hulle het die manna gekry omdat God dit vir hulle gegee het en nie noodwendig omdat Moses daar was nie daarin lê die belang van die manna. As God nou vir hulle ander brood gee, moet hulle dit aanvaar, want dit is nie Moses wat tel nie, maar God. Dit is juis hierdie argumentasielyn wat verder in die hoofstuk opgeneem word. In 6:49 wys Jesus op die feit dat die voorouers gesterf het, al het hulle die brood geëet. Mense wat die brood eet wat God nou gee, sal nie sterf nie. Dit dui nie alleen op die kwalitatiewe onderskeid tussen die twee soorte brood nie, maar vestig ook ' $n$ nuwe groep (volk) wat van God se brood kry en eet - die wat in Jesus glo sal in die familie van God opgeneem word (die ewige lewe kry) - dit word in soveel woorde in

${ }^{87}$ Sien Schanckenburg (1968:429) oor die belang van voorouers vir die Samaritane. ${ }^{88}$ Sien Schnelle (1998:89) oor die belang van die kultusoord. Carson (1991:221222).

${ }^{89}$ Sien Barrett (1978:290-292) vir ' $n$ goeie bespreking van die mannatradisie en die Ou Testament.
6:58 gesê $\hat{e}^{90}$. Ook in hierdie geval word die aardse verwantskappe as kontras gebruik vir die baie beter verwantskap wat Jesus bring, naamlik die familie van God.

In hoofstuk 8 beroep die Jode hulle op Abraham as hulle voorvader om so hulle identiteit as vry mense te beskryf (8:33). Jesus bevestig dit hulle is kinders van $\mathrm{Abraham}^{91}$, maar al probleem is dat hulle nie so optree nie (8:37). Aangesien kinders soos hulle ouers moet optree (8:38) skep dit vir die Jode ' $n$ identiteitsprobleem" ${ }^{92}$, want wie is hulle werklike voorvader as daar na hulle optrede gekyk word? Die vraag word in 8:44 beantwoord: die duiwel! Soos in die geval met die mannagesprek betwis Jesus nie hulle voorvaderlike wortels nie, maar herinterpreteer dit in die lig van geestelike verwantskap ${ }^{93}$. Moses en Abraham is maar net belangrik omdat hulle aan die kant van God gestaan het. Dit is uiteindelik God wat alleen belangrik is. Daarom moet eerder gevra word aan watter geestelike familie 'n persoon behoort. Jesus kom gee mense die geleentheid om seker te kan wees en deur Hom aan die familie van God deel te kry. In 8:56-58 verwys Jesus juis hierna. Hy was voor Abraham wat Hom in die "goddelike (pre-eksistente) geslagslyn" plaas. Nie Abraham is die ou aartsvader nie, maar Jesus was voor hom daar. Abraham kon maar net bly wees oor Jesus se verskyning, wat natuurlik ook Jesus se koms legitimeer vanuit die aartsvaderlike perspektief. Ook in die geval van hoofstuk 8 word dieselfde tendens aangetref: die aardse familiale verbondenheid word teenoor die figuurlike hemelse verbondenheid gestel en die relatiwiteit van eersgenoemde word aangetoon. Die gelowiges moet liewer lojaliteit teenoor die figuurlike hemelse familie koester as om hulle identiteit aan aardse families te bind. Aardse relasies is relatief en jy kan selfs deur jou dade toon dat jy nie (meer) aan daardie familie behoort nie.

' $\mathrm{n}$ Ander kort opmerking oor voorvaders in die Evangelie bevestig hierdie tendens. In 7:42 word daar verwys na die Christus wat uit die geslag van Dawid moet kom $^{94}$. Die outeur van die Evangelie ignoreer egter hierdie tradisie en koppel dit geensins aan Jesus nie. Jesus se wortels en identiteit word nie bepaal deur hierdie aardse verbondenhede

90 "Hierdie brood wat uit die hemel gekom het, is nie soos die manna wat julle voorouers geëet het nie. Hulle het dit geëet en tog gesterwe. Wie hierdie brood eet, sal ewig lewe".

${ }^{91}$ Soos Barrett (1978:346) tereg argumenteer, erken Jesus dit in 'n sekere sin, maar die werklike familie wat tel is die familie van God of Satan. Sien ook Carson (1991:349-350), Kysar (1986:141), Lindars (1987:326).

${ }_{92}$ Sien Calvert (1992:6), Kysar (1986:143).

${ }^{3}$ "In fact the true descendants of 'our father Abraham' are redefined radically, not as his descendants by blood, but those who acknowledge Jesus..." (Barton 1992:228). Sien ook Carson (1991:351)

${ }^{94}$ Sien Barrett (1978:330-331), Carson (1991:329) vir verdere bespreking hiervan.

ISSN 1609-9982 = VERBUM ET ECCLESIA Jrg 22 (1) 2001 
nie. Hy kom van die figuurlike hemelse Vader (1:1, 18; 3:15-16 ens) en binne daardie konteks moet sy identiteit gesoek word ${ }^{95}$. Die duidelike en ooglopende ignorering van die Dawidtradisie in die Evangelie is dus nie eienaardig nie, maar val binne die breë tendens van die Evangelie om die waarde van die aardse tradisie te minimaliseer ten gunste van die figuurlike hemelse familie wat Jesus tot stand kom bring ${ }^{96}$.

\subsection{Vaders en broers}

Daar is telkens verwysings na "vaders", maar dit wil voorkom of dit in hierdie gevalle bloot identifiserende gebruike is (soos ons vandag vanne sou gebruik - sien $1: 42 ; 13: 2,26 ; 21: 2,15,16,17$ ) en ons nie veel meer daaruit moet aflei nie ${ }^{97}$. Dit wil bloot die persoon plaas binne sy sosiale raamwerk sonder om bewustelik te veel klem te lê op die sosiale kenmerke van daardie familie.

Dieselfde blyk waar te wees van die verwysings na broers of susters. $\alpha \delta \in \epsilon \phi o ́ s$ word byvoorbeeld in $1: 40,41^{98} ; 2: 12 ; 6: 8 ; 7: 3,5,10^{99}$; $11: 2,19,21,23^{100}, 32$ gebruik $^{101}$. In 19:25 word daar bloot na Maria se suster verwys ${ }^{102}$ en in 11:1 word die susters Marta en Maria genoem.

\section{SLOT}

Osiek en Balch ${ }^{103}$ is beslis nie korrek as hulle beweer dat daar min informasie in die Evangelie oor families is nie. Daar is heelwat inligting, soos uit die bespreking geblyk het. Twee tendense is duidelik in die ondersoek uitgewys.

(a) Daar is verwysings na broers of vaders wat volgens die antieke konvensie die persone net wil identifiseer en van ander wil onderskei. Dit funksioneer byna soos vanne vandag en weerspieël die gewone konvensie van daardie tyd.

\footnotetext{
${ }^{95}$ So Schnelle (1998:149). Schnelle wil ook daarmee rekening hou dat Nasaret en nie Bethlehem nie moontlik die werklike geboorteplek van Jesus kon wees.

${ }^{96}$ In 7:22 is daar ook ' $n$ verwysing na ' $n$ aartsvader as dit gaan om die instelling van die besnydenis. In die gedeelte word die verwysing in ' $n$ argument teen die Jode gebruik om ' $n$ inkonsekwensie in hulle argumentasiegang uit te wys.

${ }_{97}$ Sien ook 4:5 waar gepraat word van Jakob se seun Josef.

${ }^{98}$ Die feit dat Andreas eers na sy broer gegaan het $(1: 41) \mathrm{mag}$ op familiale lojaliteit dui en is dus te wagte.

${ }^{99}$ Daar mag ook in die verwysings in hoofstuk 7 ' $n$ ironiese ondertoon wees, wat die vermelding van sy broers dus om ' $n$ ander rede belangrik maak.

${ }^{100}$ In hoofstuk 11 speel die familiebande tussen Marta, Maria en Lasarus tog ' $n$ rol Dit is vroeër reeds bespreek.

${ }^{101}$ In 20:17 en 20:23 word die woord á $\delta € \lambda \phi o ́ s$ figuurlik/teologies gebruik.

${ }^{102}$ Sien Barrett (1978:551) vir die familieverhoudinge.

${ }^{103}$ Osiek en Balch $(1997: 143,162)$
}

(b) Die oorgrote meerderheid van verwysings na aardse families het egter ' $\mathrm{n}$ teologiese funksie. Deurgaans word die aardse families met die figuurlike hemelse familie gekontrasteer. Die aardse familie word dan as onbelangrik beskryf, gemeet aan die figuurlike hemelse familie. Die figuurlike hemelse familie is die familie wat eintlik tel en wat as werklike familie gesien moet word. Van daaruit word ' $n$ mens se loja liteit en identiteit bepaal. Dit geld beide van Jesus en van sy volgelinge. Hulle behore aan daardie familie bepaal eintlik hulle werklike identiteit.

Maria is natuurlik ' $n$ uitsondering. As moeder van Jesus word sy in die twee kontekste waar sy vermeld word positief hanteer. Sy sien die hemelse verbondenheid van Jesus in en tree as aardse moeder dienooreenskomstig op. Sy lê haar aardse regte neer omdat sy verstaan dat Jesus sy hemelse Vader se familie kom vestig.

Die vraag waarvoor dit ' $n$ mens plaas is: Wat sê hierdie gegewens in die Evangelie vir die sogenaamde Johannese gemeenskap(pe)? Daar is ' $n$ duidelike tendens om die belang van die aardse familie, selfs die aardse Israelverbondenheid, te relativeer as van geen werklike belang nie. Die werklike familiale belang wat ook ' $n$ mens se identiteit bepaal, is jou verbondenheid aan die figuurlike hemelse familie van God. Van daaruit moet jy jouself definieer en jou optrede bepaal. So ' $n$ duidelik tendens kan eintlik maar net dui op ' $n$ groep wat nuwe sosiale grense teenoor die vasgestelde aardse sosiale grense geformuleer het. Hulle vorm ' $n$ nuwe gemeenskap met nuwe reëls op grond van nuwe familiale verhoudings. Ou aardse verbondenhede en lojaliteite het dus nie meer ' $n$ aanspraak op hulle nie, hoewel hulle nog binne daardie verhoudings leef. Die wyse waarop die Evangelie hulle verhouding met hierdie ouer verwantskappe hanteer toon ook dat die boodskap gedien het as legitimering vir hulle nuwe wyse van dink oor hulleself ${ }^{104}$.

Die Johannesgemeente was inderdaad 'n nuwe gemeenskap wat los van konvensionele aardse verbondenhede hulle lojaliteit aan 'n figuurlike hemelse familie toegesê het. Dit verklaar ook waarom die Evangelie kan sê dat aardse mense deel van die figuurlike hemelse familie is. Hulle woon nog op aarde, eet en drink en tree hier op, maar as dit om hulle lojaliteit en identiteit gaan, is daar vir hulle net een familie wat allesbepalend is en dit is die figuurlike familie van God.

Hoe pas hierdie Johannese gegewens by die tradisie van die maagdelike geboorte in? Soos vroeër bespreek, word die maagdelike geboorte nie in die Evangelie aangetref nie. Barrett (1978:295) sê "John nowhere affirms the belief in the virgin birth of Jesus, but it is probable that he knew and accepted the doctrine (see on 1:13)..." As ' $n$ mens tog na die motief vir die beskrywing van die maagdelike geboorte in die ander

${ }^{104}$ Daarom is dit nie korrek om die boodskap van die Evangelie binne ' $n$ gnostiese raamwerk te interpreteer nie.

ISSN 1609-9982 = VERBUM ET ECCLESIA Jrg 22 (1) 2001

175 
evangelies kyk, staan die Johannesevangelie nie ver daarvandaan nie. Jesus se optrede wys dat hy van God moet kom, soos die Proloog sê $(1: 14,18)$. Sy identiteit moet dus in die "bo", oftewel die hemel, gesoek word. Dit bevestig juis die goddelikheid van Jesus. Sy oorsprong is nie op hierdie aarde te vinde nie, maar in die hemel. In die sin is die motief rondom Jesus se herkoms analoog met wat in die Sinoptiese Evangelies deurgegee word. Die verhaal word in die Johannesevangelie vanuit ' $n$ hemelse perspektief vertel, terwyl Matteus en Lukas dit vanuit die aardse perspektief vertel - Jesus is die Seun van God in oorsprong.

\section{Literatuurverwysings}

Barrett, C K 1978. The Gospel according to St John, London: SPCK.

Barton, S C 1992. Children in: Dictionary of Jesus and the Gospels, Green J B, McKnight S, Marshall, I H (eds) Leicester: IVP, 100-104.

Barton, S C 1992. Family in: Dictionary of Jesus and the Gospels, Green J B, McKnight S, Marshall, I H (eds) Leicester: IVP, 226-229.

Bösen, W 1998. Galiläa, Feiburg: Herder.

Brown, R 1971. The Gospel according to John I-XII, London: Chapman.

Brown, R 1972. The Gospel according to John XIII-XXI, London: Chapman.

Bultmann, R 1978. Das Evangelium des Johannes, Göttingen: Vandenhoeck \& Ruprecht.

Calvert, N L 1992. Abraham in: Dictionary of Jesus and the Gospels, Green J B, McKnight S, Marshall, I H (eds) Leicester: IVP, 3-7.

Carson, D A 1991. The Gospel according to John, Grand Rapids: Eerdmans.

Dodd, C H 1978. The interpretation of the Fourth Gospel, Cambridge: CUP.

Dodd, C H 1979. Historical tradition in the Fourth Gospel, Cambridge: CUP.

Ferguson, E 1990. Backgrounds of Early Christianity, Grand Rapids: Eerdmans.

Käsemann, E 1968. The Testament of Jesus, London: SCM.

Kysar, R 1986. John, Minneapolis: Augsburg Publishing.

Lindars, B 1987. The Gospel of John,: Grand Rapids: Eerdmans.

Malina, B J, Joubert, S J en Van der Watt, J G 1995. Vensters wat die Woord laat oopgaan, Pretoria: Orion.

Malina, B J en Neyrey, J H 1996. Portraits of Paul. An archaeology of ancient personality, Louisville, Kentucky: Westminster John Knox.

Neyrey, J H 1996. The trials (forensic) and tribulations (honor challenges) of Jesus: John 7 in Social Sciene Perspective, BTB 26(3), 107-124.

Osiek, C en Balch, D L 1997. Families in the New Testament World. Households and House Churches, Louisville: Westminster John Knox.

Porsch, F 1988. Johannesevangelium, Stuttgart: Katholisches Bibelwerk.

Schenke, L 1998. Johannes Kommentar, Düsseldorf: Patmos.

Schnackenburg, R 1968. The Gospel according to St John, New York: Herder and Herder.

Schnackenburg, R 1980. The Gospel according to St John, London: Burns \& Oats.

Schnackenburg, R 1982. The Gospel according to St John, London: Burns \& Oats.

Schnelle, U 1998. Das Evangelium nach Johannes, Leipzig: Evangelische Verlagsanstalt.

$\mathrm{V}$ an der Watt, J G 2000. Family of the King. Dynamics of metaphor in the Gospel according to John, Leiden: Brill.
Wilckens, U 1998. Das Evangelium nach Johannes, Göttingen: Vandenhoeck \& Ruprecht. 